\title{
Phospholipase $D$ is activated and phosphorylated by casein kinase-II in human U87 astroglioma cells
}

\author{
Bong-Hyun Ahn ${ }^{1 *}$, Gyesik Min $^{2 *}$, \\ Yoe-Sik $\mathrm{Bae}^{3}$, Young-Seuk Bae ${ }^{4}$ \\ and Do Sik Min ${ }^{5,6}$
}

${ }^{1}$ Cardiovascular Branch National Heart

Lung and Blood Institute (NHLBI)

NIH Bldg 10/CRC 5-3288, 10 Center Drive

Bethesda, MD 20892, USA

${ }^{2}$ Department of Microbiological Engineering

Jinju National University

Chilam-dong 150, Jinju 660-758, Korea

${ }^{3}$ Medical Research Center for Cancer

Molecular Therapy and Department of Biochemistry

College of Medicine, Dong-A University

Busan 602-714, Korea

${ }^{4}$ Department of Biochemistry

College of Natural Sciences, Kyungpook National University

Daegu 702-701, Korea

${ }^{5}$ Department of Molecular Biology

College of Natural Science, Pusan National University

Busan 609-735, Korea

${ }^{6}$ Corresponding author: Tel, 82-51-510-3682;

Fax, 82-51-513-9258; E-mail, minds@pusan.ac.kr

${ }^{*}$ These authors contributed equally to this work.

Accepted 17 January 2006

Abbreviations: CKII, casein kinase II; PKC, protein kinase C; PLD, phospholipase D; PtdBut, phosphatidylbutatol

\footnotetext{
Abstract

Elevated expression of protein casein kinase II (CKII) stimulated basal phospholipase D (PLD) activity as well as PMA-induced PLD activation in human U87 astroglioma cells. Moreover, CKII-selective inhibitor, emodin and apigenin suppressed PMA-induced PLD activation in a dose-dependent manner as well as basal PLD activity, suggesting the involvement of CKII in the activation of both PLD1 and PLD2. CKII was associated with PLD1 and PLD2 in co-transfection experiments. Furthermore, CKII induced serine/threonine phosphorylation of PLD2 in vivo, and the multiple regions of PLD2 were phosphorylated by CKII in vitro kinase assay using glutathione S-transferase-PLD2 fusion protein fragments. Elevated expression of CKII or PLD increased cell proliferation
}

but pretreatment of cells with 1-butanol suppressed CKII-induced cell proliferation. These results suggest that CKII is involved in proliferation of U87 cells at least in part, through stimulation of PLD activity.

Keywords: casin kinase II; cell proliferation; phospholipase D; phosphorylation

\section{Introduction}

Protein kinase CKII is a ubiquitous and highly conserved Ser/Thr kinase, found in various subcellular compartments in eukaryotes. It exists as a constitutively active tetramer that contains two catalytic subunits, $\alpha$ or $\alpha^{\prime}(37-44 \mathrm{kDa})$, and two regulatory $\beta$ subunits (24-28 kDa) (Allende and Allende, 1995; Pinna and Meggio, 1997; Litchfield, 2002). The two catalytic subunits are highly homologous, but the $\alpha$ ' subunit has a unique required role in spermatogenesis $(\mathrm{Xu}$ et al., 1999). CKII phosphorylates serine or threonine in acidic domains, with $(\mathrm{S} / \mathrm{T}) \mathrm{XX}(\mathrm{D} / \mathrm{E})$ being the canonical motif (Hrubey and Roach, 1990; Marin et al., 1992). CKII was postulated to contribute to tumorigenesis because its activity is enriched in many human solid tumors, transformed cell lines, and rapidly proliferating tissues (Ahmed, 1994; Daya-Makin et al., 1994). Dysregulated expression of CKII in cells can be oncogenic, as transgenic expression of CKIla can promote lymphoma (Seldin and Leder, 1995; Kelliher et al., 1998; Landesman-Bollag et al., 1998) and breast cancer (Landesman-Bollag et al., 2001). In addition, it has been demonstrated that CKII catalyzes the phosphorylation of several oncogene products such as Myc, Myb, Jun, Fos, p53, and Rb (Pinna, 1990; Issinger, 1993; Allende and Allende, 1995). These observations suggest that CKII plays a critical role in cell proliferation and oncogenesis.

Phospholipase D (PLD) catalyzes the hydrolysis of phosphatidylcholine (PC), the major membrane phospholipids, to form phosphatidic acid (PA) and choline (Exton, 1998). PA can alter the activities of many enzymes and proteins (Andresen et al., 2002) and can be further metabolized to diacylglycerol (DAG) and lysophosphatidic acid by PA phosphohydrolase and phospholipase A2, respectively. Thus, PLD influences many important intracellular events via producing these downstream products. PLD activity is regulated by many stimuli such as cytokine, growth factors, hormones, neurotrans- 
mitters, and other molecules involved in extracellular communication (Exton, 1998). PA is generally recognized as the signaling product of PLD and functions as an effector in multiple physiological process including cell proliferation, differentiation, secretion, and migration. In mammals, two isoforms of PLD, PLD1 and PLD2, have been cloned and are being characterized for regulation and cellular function (Frohman and Morris, 1999). However, segregated roles of the two PLD isoforms in cellular responses are still poorly understood. Activation of PLD occurs through interactions of the ARF and Rho families as well as protein kinase $C$ (PKC) (Frohman and Morris, 1999). The relative contribution of these factors to PLD activation is highly dependent on the cell type and signaling model examined. Consistent with a complex set of regulatory requirements, PLD appears to contain several different post-translational modifications. We have reported that PLD can be phosphorylated on tyrosine residues by $\mathrm{c}-\mathrm{Src}$ and the combination of $\mathrm{H}_{2} \mathrm{O}_{2}$ and vanadate (Min et al., 1998; Ahn et al., 2003; Kim et al., 2004b). In addition, PLD1 is phosphorylated on serine and threonine residue by PKC (Min et al., 1998; Kim et al., 2000). In the present study, we report that CKII is involved in PMA-induced PLD1 and PLD2 activation, phosphorylates PLD2 and interacts with both PLD1 and PLD2. Our results suggest that CKII is involved in proliferation of U87 cells at least in part, through stimulation of PLD activity

\section{Materials and Methods}

\section{Reagents}

Glutathione-sepharose 4B was from Amersham Bioscience Biotech. Anti-phospho-ser/thr antibody was from Zymed. The antibody to CKII- $\alpha$ was from Santa Cruz. Emodin, apigenin and PMA were from Sigma. Calphostin C was purchased from Biomol Research Laboratories (Plymouth Meeting, PA). A polyclonal antibody that recognizes both PLD1 and PLD2 was generated as previously described (Min et al., 2001). Phosphatidylbutanol (PtdBut) standard was from Avanti Polar Lipid. [9, $\left.10-{ }^{3} \mathrm{H}\right]$ myristate was purchased from PerkinElmer Life Sciences. Silica gel 60 A thin layer chromatography plates were from Whatman. Horseradish peroxidase-conjugated antimouse $\lg G$ and anti-rabbit $\lg G$ were from Kirkegaard \& Perry Lab (Gaithersburg, MD). The ECL Western blotting detection kit was from Amersham Bioscience. Human CKII was purified homogeniety via four chromatography steps using DEAE-cellulose, phosphocellulose, heparin-agarose, and gel filtration from the lysates of $E$. Coli that expressed both $\alpha$ and $\beta$ subunits of CKII (Kim et al., 1998).

\section{Cell culture and transfections}

U87 MG human astroglioma was obtained from the American Type Culture Collection (Rockville, MD). The cells were maintained in DMEM (Life Technologies, Inc) supplemented with $10 \%$ (v/v) fetal bovine serum under $5 \% \quad \mathrm{CO}_{2}$. U87 cells were transiently transfected for $40 \mathrm{~h}$ with expression plasmid using LipofectAMINE (Invitrogen) according to manufacturer's instructions. U87 cells stably overexpressing PLD isozyme were obtained by transfection, using LipofectAMINE. Transfected cells were selected with G418 $(700 \mu \mathrm{g} / \mathrm{ml})$ for 21 days at $37^{\circ} \mathrm{C}$. At that time antibiotics-resistant colonies were pooled and expanded for further analysis under selective conditions.

\section{PLD activity assay}

PLD activity was assessed by measuring the formation of $\left[{ }^{3} \mathrm{H}\right]$ phosphatidylbutanol (PtdBut), the product of PLD-mediated transphosphatidylation, in the presence of 1-butanol. After $20 \mathrm{~h}$ transfection with LipofectAMINE, U87 cells in 6-well plates were serumstarved in the presence of $1 \mu \mathrm{Ci} / \mathrm{ml}\left[{ }^{3} \mathrm{H}\right]$ myristic acid. After overnight starvation, the cells were washed three times with $5 \mathrm{ml}$ of phosphate-buffered saline (PBS) and pre-equilibrated in serum-free DMEM for $1 \mathrm{~h}$. For the final $10 \mathrm{~min}$ of preincubation, $0.3 \%$ butan-1-ol was included. At the end of the preincubation, cells were treated with agonists for the indicated times. The extraction and characterization of lipids by thin-layer chromatography were performed as previously described (Kim et al., 2004a).

\section{Construction and preparation of GST fusion proteins}

GST fusion proteins of PLD2 fragments were constructed as described previously (Kim et al., 2002). The PCR products were digested with the restriction enzymes and inserted into pGEX-4T1 vector (Amersham Pharmacia Biotech). E. coli BL21 cells were transformed with the individual expression vectors encoding the GST fusion protein, and after harvesting the cells, GST fusion proteins of PLD2 fragments were purified as described previously (Kim et al., 2002).

\section{Immunoprecipitation}

Cells were washed twice with ice-cold phosphatebuffered saline and then lysed in the extraction buffer (20 mM Hepes, pH 7.2, 1\% Triton X-100, 1\% sodium deoxycholate, $0.2 \%$ SDS, $200 \mathrm{mM} \mathrm{NaCl}, 1 \mathrm{mM}$ $\mathrm{Na}_{3} \mathrm{VO}_{4}, 1 \mathrm{mM} \mathrm{NaF}, 10 \%$ glycerol, $10 \mu \mathrm{g} / \mathrm{ml}$ leupeptin, $10 \mu \mathrm{g} / \mathrm{ml}$ aprotinin, $1 \mathrm{mM}$ phenymethylsulfonyl fluoride). The resulting cell lysates was spun at 15,000 $\times g$ in a Eppendorf microcentrifuge for $10 \mathrm{~min}$ at $4^{\circ} \mathrm{C}$ to pellet the unbroken cells. The supernatant 
A

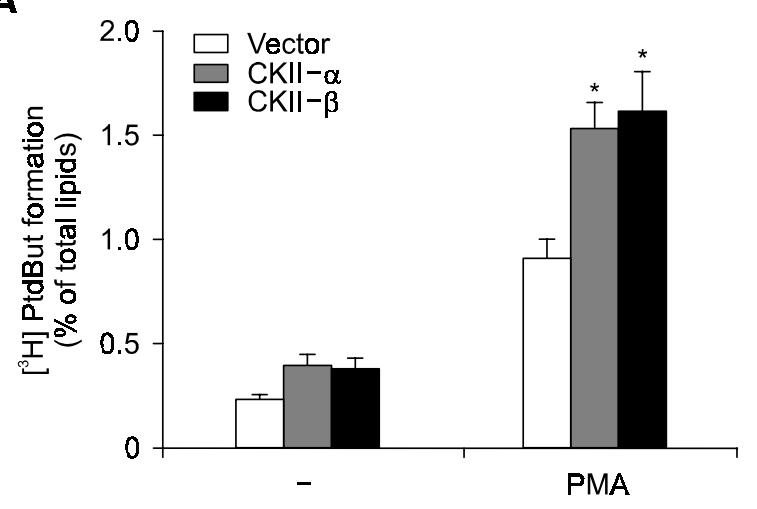

C

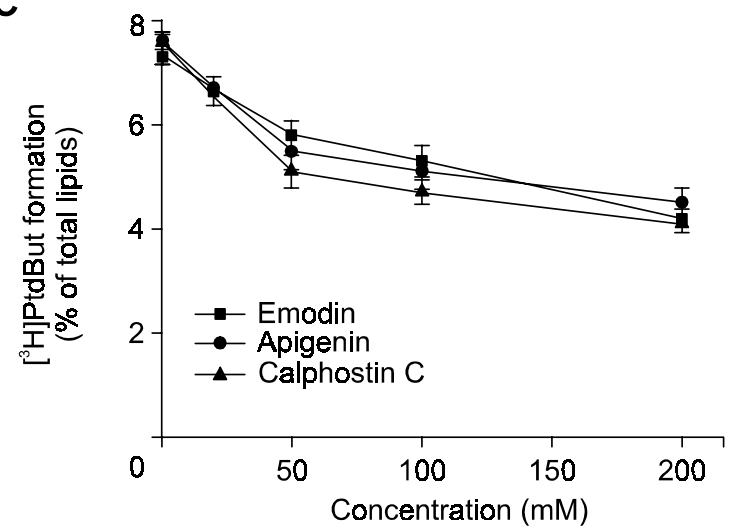

E

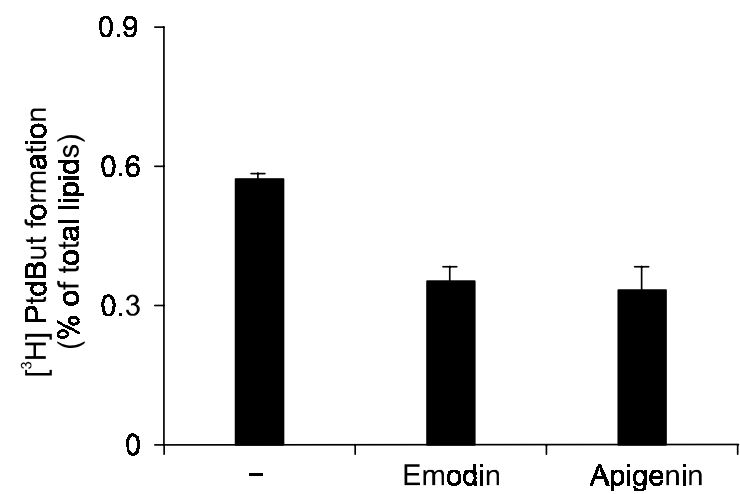

B

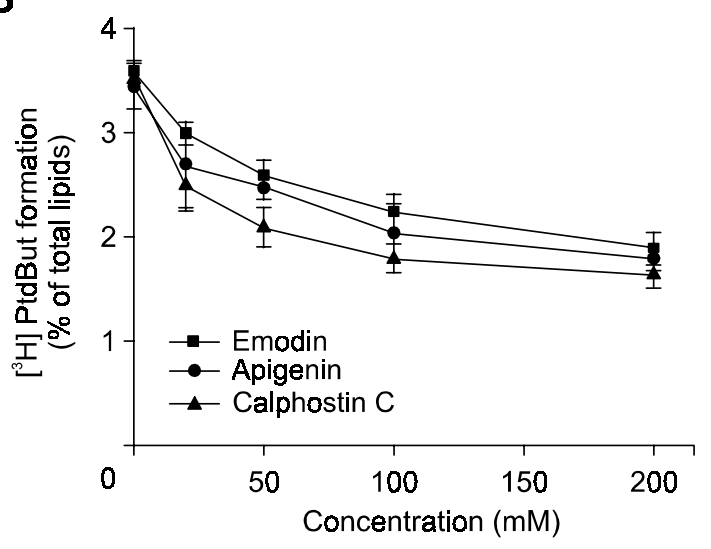

D



Figure. 1 CKII is involved in PMA-induced PLD activation. (A) U87 cells were transiently transfected with CKII- $\alpha$ or $\beta$, labeled with $\left[{ }^{3}\right.$ H]myristic acid, and treated with $100 \mathrm{nM}$ PMA for $1 \mathrm{~h} .{ }^{*} P<0.05$ compared to cells transfected with vector and treated with PMA. U87 cells overexpressing PLD1 $(B)$ and PLD2 $(C)$ were labeled with $\left[{ }^{3} \mathrm{H}\right]$ myristic acid, preincubated with the indicated concentrations of emodin, apigenin, or calphostin $\mathrm{C}$ and stimulated with PMA for 1h. (D) U87 cells over-expressing PLD1 (P1), PLD2 (P2) or vector were treated with or without emodin $(\mathrm{E}, 100 \mu \mathrm{M})$ and calphostin $\mathrm{C}(\mathrm{C}, 100 \mu \mathrm{M})$. PLD expression was analyzed by Western blot using antibody to PLD which recognizes both PLD1 and PLD2. (E) U87 cells were incubated with or without emodin $(100 \mu \mathrm{M})$ and apigenin $(100 \mu \mathrm{M})$. The radioactivity incorporated into phosphatidylbutanol was measured as described in Materials and Methods. Results are means \pm S.D of three independent experiments.

was then precleared for 30 min with preimmune $\operatorname{lgG}$ and protein $\mathrm{A}$ sepharose at $4^{\circ} \mathrm{C}$ with rocking. Protein concentrations were determined using Bradford method with bovine serum albumin as a standard (4).
Equal protein aliquots of precleared cell lysates (1 $\mathrm{mg}$ ) were incubated with the indicated antibodies and $40 \mu \mathrm{l}$ of a $1: 1$ slurry of protein $A$ sepharose beads for $4 \mathrm{~h}$ at $4^{\circ} \mathrm{C}$. The immune complexes were 
collected by centrifugation and washed five times with a buffer (20 mM Tris, $\mathrm{pH} 7.5,1 \mathrm{mM}$ EDTA, $1 \mathrm{mM}$ EGTA, $150 \mathrm{mM} \mathrm{NaCl}, 2 \mathrm{mM} \mathrm{Na}_{3} \mathrm{VO}_{4}, 10 \%$ glycerol and $1 \%$ Nonidet $\mathrm{P}-40$ ) and resuspended in sample buffer. Immune complexes were boiled in SDS-sample buffer.

\section{Western blotting}

Proteins samples were analyzed by SDS-polyacrylamide gel electrophoresis and were transferred to a nitrocellulose membrane. The blots were then blocked with $5 \%$ non-fat milk and incubated with appropriate primary antibodies followed by incubation with horseradish peroxidase-conjugated secondary antibody. Immunoreactive bands were detected using enhanced chemiluminescence.

\section{In vito kinase assay}

Kinase assays were performed using $250 \mathrm{ng}$ of GST-PLD2 fragments as substrate. GST-PLD2 fragment were incubated with $500 \mathrm{ng}$ of purified CKII in $30 \mu$ of kinase buffer $(20 \mathrm{mM}$ Tris- $\mathrm{HCl}, \mathrm{pH} 7.4$,

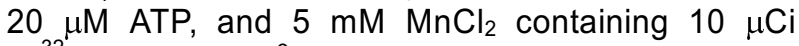
$\left.\left[\gamma^{32} \mathrm{P}\right] \mathrm{ATP}\right)$ at $37^{\circ} \mathrm{C}$ for $10 \mathrm{~min}$. Kinase reactions were terminated by addition of SDS-PAGE loading buffer with $\beta$-mercaptoethanol, boiled for $5 \mathrm{~min}$, separated by SDS-PAGE, and exposed to film.

\section{Cell proliferation assay}

Cells in 96-well plates were seeded in DMEM supplemented with $10 \%$ fetal bovine serum and incubated with emodin or apigenin at $37^{\circ} \mathrm{C}$ for $24 \mathrm{~h}$. Afterwards, cells were incubated for $2 \mathrm{~h}$ with CellTiter 96 Aqueous (MTS) solution, absorbance of coloured MTS products in the supernatant was determined on ELISA reader at $495 \mathrm{~nm}$.

\section{Results and Discussion}

\section{CKII is involved in PMA-induced PLD activation}

Many substrates of CKII are involved in signal transduction pathways (Blanquet, 2000). In most cases, phosphorylation of these substrates occurs following their interaction with the kinase. However, despite some advances, the significance of these events remains to be clarified or is still quite enigmatic. It has been suggested that CKII might have potentially important roles in neuronal function such as neuronal differentiation and proliferation (Blanquet, 2000). It was demonstrated that PKC stimulation via phorbol ester treatment increases CKII activity (Sanghera et al., 1992; Silva-Neto et al., 2002). PKC is also known to stimulate PLD activity (Frohman and Morris, 1999). Recently, it has been reported that CKII interacts with PLD1 (Ganley et al., 2001). Thus, we investigated whether CKII affects agonistinduced PLD activation in human U87 astroglioma cells. CKII- $\alpha$ or $\beta$ subunit was transiently transfected in U87 astroglioma cells, and the cells were stimulated with or without $4 \beta$-phorbol 12-myristate 13acetate (PMA). Interestingly, both $\mathrm{CKII-} \alpha$ and $\beta$ subunit stimulated basal PLD activity as well as PMAinduced PLD activation (Figure 1A). To confirm that CKII is involved in PMA-induced PLD activation, we used CKII-specific inhibitiors, emodin and apigenin. Moreover, we used U87 cells expressing PLD1 and PLD2 to examine which isozyme of PLD activity is affected by CKII. As shown in Figure $1 \mathrm{~B}$ and $\mathrm{C}$, These inhibitor suppressed in a dose-dependent manner PMA-induced PLD activation and showed similar potency in inhibiting PLD activity. Calphostin $C$, PKC inhibitor as a positive control, inhibited activation of PLD by PMA. Emodin and apigenin suppressed PLD1 or PLD2 activity as well as basal PLD activity (Figure 1D, E) and. These drugs did not affect the expression of PLD isozymes. These results suggest that $\mathrm{CKI}$ is involved in PMA-induced PLD1 or PLD2 activation as well as basal PLD activity.

\section{CKII interacts with PLD1 and PLD2}

Little is known about CKII regulation except for the well-characterized multiple dimerization combinations between the two catalytic subunits ( $\alpha$ and $\alpha^{\prime}$ ) and the regulatory subunit $(\beta)$ that maximizes its kinase activity (Allende and Allende, 1998). However, recent studies indicate that CKII may form heterocomplexes with unrelated kinases and potentially modify its function (Bren et al., 2000). Atypical PKC directly interact with CKII, and hence potentially regulates its activity (Bren et al., 2000). To examine whether the interaction of CKII with PLD is involved in PLD activation by CKII, we tried to perform cotransfection experiments in U87 cells using its expression vector. After transfection, cell lysates were prepared and subjected to immunoprecipitation using an antibody directed against PLD or CKII- $\alpha$, and monitored by successive immunoblotting for CKII- $\alpha$ or PLD. The data presented in Figure 2 show that anti-PLD antibody and anti-CKII- $\alpha$ antibody, but not non-immune IgG (NG), immunoprecipitates CKII- $\alpha$, and PLD, respectively. These results suggest that CKII- $\alpha$ associates with both PLD1 and PLD2.

\section{CKII phosphorylates PLD2}

It has been reported that CKII phosphorylates PLD1 and this phosphorylation event does not influence PLD1-mediated hydrolysis of phosphatidylcholine in vitro (Ganley et al., 2001). In this study, we found 


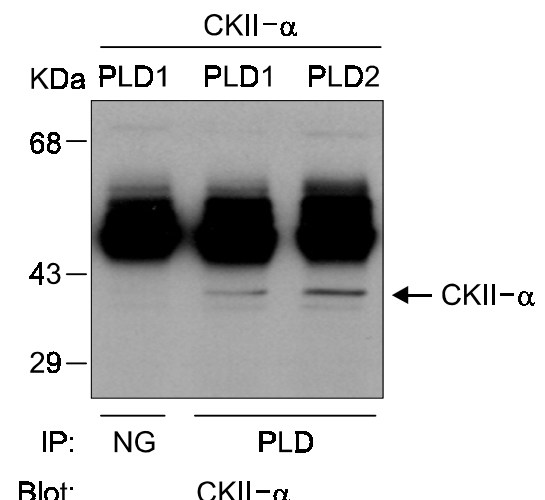

Blot: $\quad$ CKII- $\alpha$

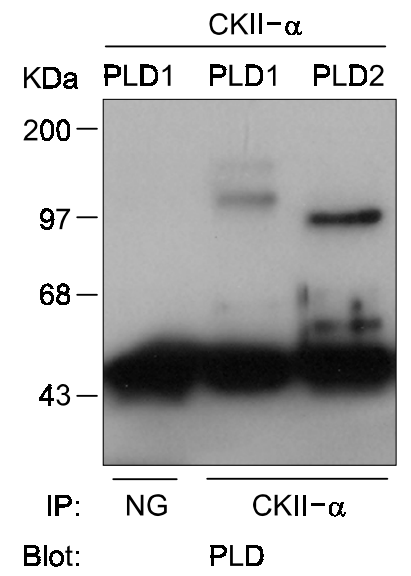

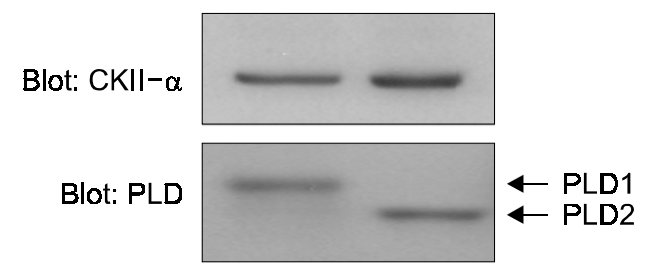

Figure 2. CKII associates with PLD isozymes. U87 cells were co-transfected with PLD1 or PLD2 and CKII- $\alpha$. Cell lysates were immunoprecipitated with non-immune IgG (NG), anti-PLD or anti-CKII- $\alpha$ antibodies and immune complexes were subjected to immunoblotting using anti-CKII- $\alpha$ or anti-PLD antibodies, respectively. Expression of PLDs and CKII- $\alpha$ were determined by immunoblotting. Data are representative of three experiments.

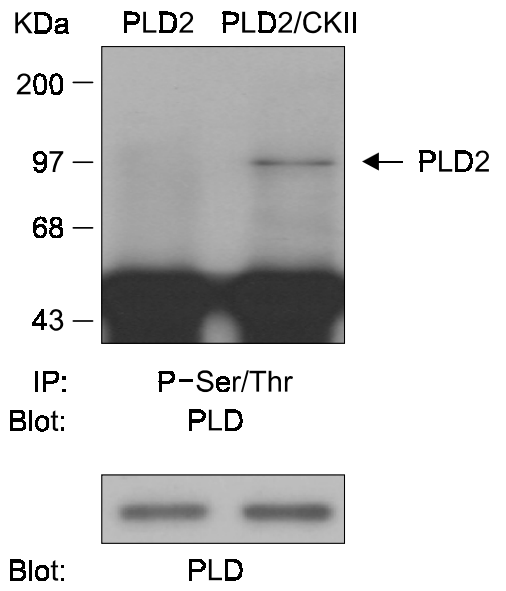

Figure 3. PLD2 is phosphorylated by CKII- $\alpha$ in co-transfection experiments. U87 cells were transiently transfected with only PLD2 or CKII and PLD2, and the cell lysates were immunoprecipitated with anti-phospho-Ser/Thr antibody. The immune complexes were analyzed by immunoblotting using anti-PLD antibody. PLD expression were determined by immunoblotting using anti-PLD antibody.

that inhibitors of CKII suppressed PMA-induced PLD1 and PLD2 activation in vivo as shown in Figure $1 \mathrm{~B}$ and $\mathrm{C}$. These results suggest that regulation of PLD activity by CKII in vitro can be different from that of in vivo. Next, we tried to examine whether CKII can phosphorylate PLD2. Transfection with only PLD2 expression vector or co-transfection with CKII$\alpha$ and PLD2 cDNA was performed in U87 cells, and the lysates were immunoprecipitaed with antiphospho-serine/threonine antibody, and analyzed by immunoblotting using anti-PLD antibody. As shown in Figure 3, anti-phospho-serine/threonine antibody immunoprecipitated PLD2 in the cells co-transfected with both expression vectors, but not in the cells transfected with only PLD2, suggesting that PLD2 is phosphorylated by CKII. In addition, we analyzed the phosphorylation site(s) of PLD2 by CKII. To identify the PLD2 sequence phosphorylatd by CKII, we constructed the GST fusion proteins shown in Figure 4A. In vitro kinase assays using purified GST-PLD2 fragments and CKII holoenzyme were performed. GST-PLD2 fragments were incubated with CKII holoenzyme in kinase buffer containing $\left[\gamma^{32} \mathrm{P}\right] \mathrm{ATP}$. The reactions were separated by SDS-PAGE, and autoradiography was performed. Multiple regions of PLD2 were phosphorylated in vitro by CKII (Figure 4B). To examine whether GST-PLD2 fragment is specifically phosphorylated by CKII, GST-PLD2 F5 fragment was used for in vitro kinase assay in the presence or absence of apigenin. As shown in Figure 4C, apigenin inhibited CKIl-induced phosphorylation of PLD2 fragment, suggesting the phosphorylation of PLD2 by CKII. These results suggest that PLD2 is phosphorylated by CKII in vivo and in vitro. Future studies are needed to identify the amino acid residues and roles of PLD2 phosphorylated by CKII.

\section{CKII inhibitors suppress proliferation of U87 astroglioma cells}

It has been reported that CKII activity increases when quiescent cells are stimulated to proliferate (Issinger, 1993; Allende and Allende, 1995; Pinna and Meggio, 1997). Studies performed using selective inhibitors also illustrate that $\mathrm{CKII}$ is required during various stages of cell cycle progression (Ford et al., 2000). Moreover, CKII activity levels are elevated in a num- 
A
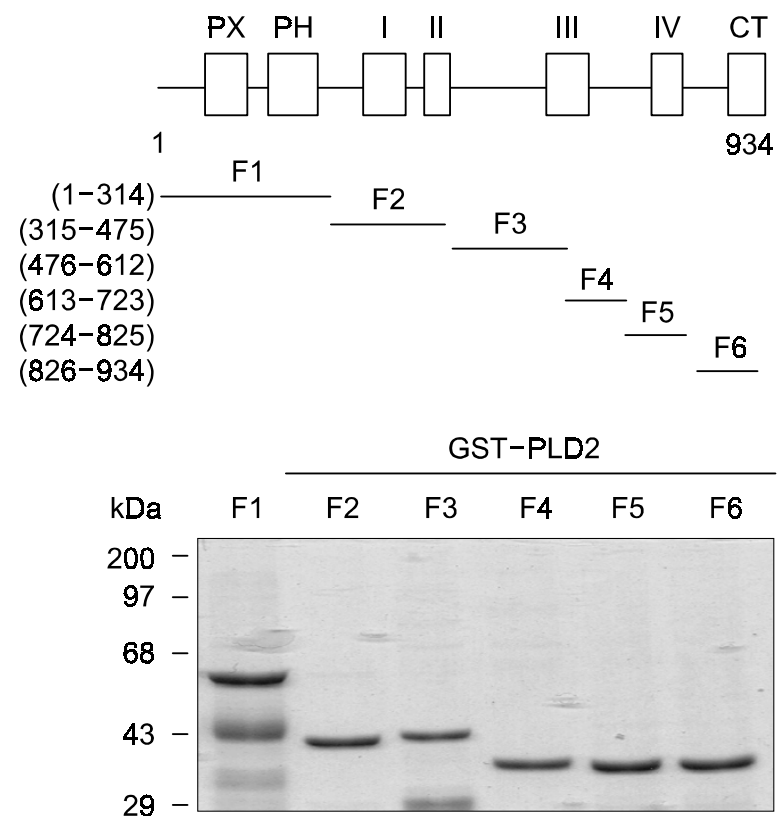

B

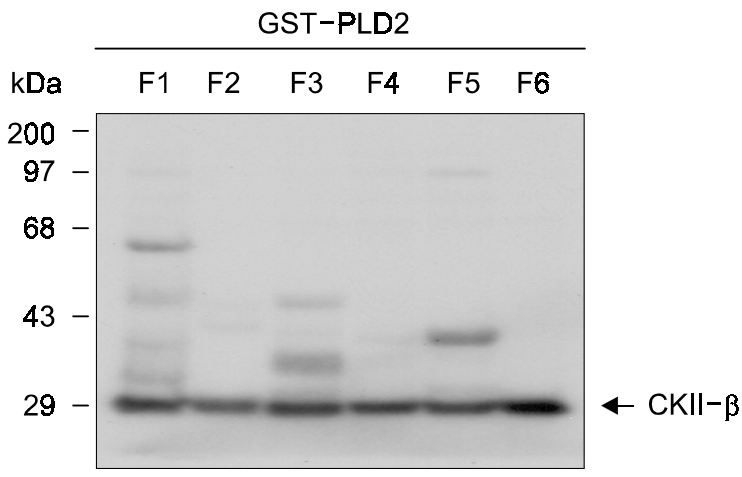

C

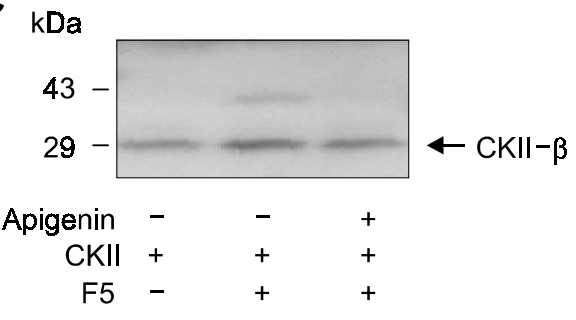

Figure 4. Multiple regions of PLD2 are phosphorylated by CKII in vitro kinase assay. (A) Primary structure and individual domains of PLD2. Boxes indicate regions of highly conserved sequences in PLD isozymes (top). PX, phox domain; PH, pleckstrin homology domain; CR I, II, III, IV, conserved region I, II, III, IV; CT, carboxyl terminus. Purified GST-fusion proteins containing different regions of PLD2 were subjected to SDS-PAGE followed by Coomassie Brilliant Blue staining (bottom). (B) GST-PLD2 fragments were incubated with CKII holoenzyme in kinase buffer containing $\left[\gamma^{32}\right.$ P]ATP at $37^{\circ} \mathrm{C}$ for $10 \mathrm{~min}$. (C) GST-PLD2 F5 fragment was incubated with or without apigenin in the presence of CKII holoenzyme in kinase buffer. The kinase reactions were terminated by addition of SDS loading with $\beta$-mercaptoethanol buffer, boiled for $5 \mathrm{~min}$, and separated by SDS-PAGE. The gels were dried and exposed to film to visualize all bands.

ber of tumors and leukemic cells. Collectively, these studies implicates CKII as an important component of signaling pathways involved in cell cycle progression and transformation. PLD also has emerged as a critical regulator of cell proliferation and survival, and prevents apoptosis (Foster, 2003). It is therefore possible that the interaction of CKII with PLD, and activation of PLD by CKII may impact cell functions. Thus, we tried to examine the possibility that blocking of PLD activity by CKII inhibitors might be involved in the suppression of cell proliferation. To assess the effect of CKII on proliferation of U87 astroglioma cells, we used the CellTiter 96 Aqueous proliferation assay that is based on metabolic conversion of a tetrazolium compound, MTS, to a coloured product by living cells. The absorbance intensity of the MTS product is directly proportional to the number of viable cells in culture. As shown in Figure 5, transfection of CKII or PLD2 significantly increased absorbance, but treatment of CKII inhibitors (emodin, apigenin) and 1-butanol which block PA production by PLD, decreased absorbance compared with that of control cells. In addition, 1-butanol suppressed CKII-induced cell proliferation. These results suggest that CKII is involved in proliferation of U87 cells at least in

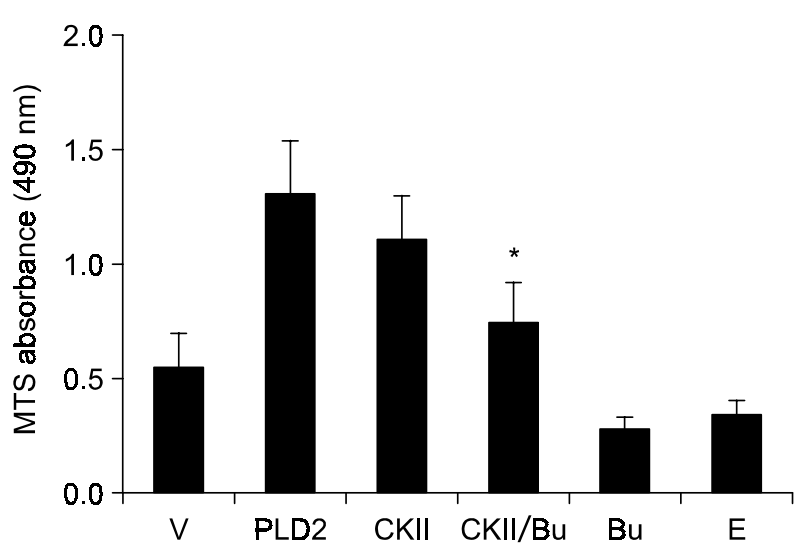

Figure 5. CKII is involved in proliferation of U87 cells in part, through stimulation of PLD activity. U87 cells were transfected with PLD2 or CKII- $\alpha$ and treated with or without 1-butanol $(0.3 \%)$, emodin (50 $\mu \mathrm{M})$ for $24 \mathrm{~h}$. The number of viable cells was determined by the CellTiter Aqueous (MTS) reagent. Differences in absorbance at 495 $\mathrm{nm}$ were plotted as relative changes in the number of live cells. ${ }^{*} P<0.05$ compared to CKII cells. Results are means \pm S.D of three independent experiments. 
part, through stimulation of PLD activity

\section{Acknowledgement}

We thank Dr. Sung Ho Ryu (POSTECH, Pohang, Korea) for providing GST-PLD2 constructs. This work was supported by the Korea Research Foundation Grant (KRF-2003-015-E00060) and by the Biotechnology Development Program (grant number 200500115) from Ministry of Science and Technology (MOST), Korea and by grant No. R01-2002-00000262-0 (2002) from the Basic Research Program of the Korea Science \& Engineering Foundation.

\section{References}

Ahmed K. Significance of the casein kinase system in cell growth and proliferation with emphasis on studies of the androgenic regulation of the prostate. Cellular and Molecular Biological Research 1994;40:1-11

Ahn BH, Kim SY, Kim EH, Choi KS, Kwon TK, Lee YH, Chang JS, Kim MS, Jo YH, Min DS. Transmodulation between phospholipase D and c-Src enhances cell proliferation. Molecular and Cellular Biology 2003;23:3103-26

Allende JE, Allende CC. Protein kinase CK2: an enzyme with multiple substrates and a puzzling regulation. FASEB Journal 1995;9:313-23

Andresen BT, Rizzo MA, Shome K, Romero G. The role of phosphatidic acid in the regulation of the Ras/MEK/Erk signaling cascade. FEBS Letter 2002;531:65-8

Blanquet PR. Casein kinase 2 as a potentially important enzyme in the nervous system. Progress in Neurobiology 2000;60:211-46

Bren GD, Pennington KN, Paya CV. PKC- $\zeta$-associated CK2 participates in the turnover of free $\mathrm{lkB} \alpha$. Journal of Nolecular Biology 2000;297:1245-58

Daya-Makin M, Sanghera JS, Morgentale TL, Lipp M, Parchomchuk J, Hogg JC, Pelech SL. Activation of a tumorassociated protein kinase (p40TAK) and casein kinase 2 in human squamous cell carcinomas and adenocarcinomas of the lung. Cancer Research 1994;54:2262-8

Exton, JH. Phospholipase D. Biochimica et Biophysica Acta 1998;1436:105-15

Ford HL, Landesman-Bollag E, Dacwag CS, Stukenberg PT, Pardee AB, Seldin DC. Cell cycle-regulated phosphorylation of the human SIX1 homeodomain protein. Journal of Biological Chemistry 2000;275:22245-54

Foster DA, Xu L. Phospholipase D in cell proliferation and cancer. Molecular Cancer Research 2003;1:789-800

Frohman MA, Morris AJ. Phospholipase D structure and regulation. Chemical Physics Lipids 1999;98:127-40

Ganley IG, Walker SJ, Manifava M, Li D, Beown A, Ktistakis NT. Interaction of phospholipase D1 with a casein-inase-2-like serine kinase. Biochemical Journal 2001;354:369-78
Hrubey TW, Roach PJ. Phosphoserine in peptide substrates can specify casein kinase II action. Biochemical and Biophysical Research Communications 1990;172:190-6

Issinger OG, Casein kinase: pleiotropic mediators of cellular regulation. Pharmacology and Theraphy 1993;59:1-30

Kelliher MA, Seldin DC, Leder P. Tal-1 induces T cell acute lymphoblastic leukemia accelerated by casein kinase Ilalpha. EMBO Journal 1996;15:5160-6

Kim J, Choi BH, Jang KL, Min DS. Phospholipase D is elevated in hepatitis $\mathrm{C}$ virus core protein-transformed NIH3T3 mouse fibroblast cells. Experimental and Molecular Medicine. 2004a;36:454-60

Kim J, Min G, Bae YS, Min DS. Phospholipase D is involved in oxidative stress-induced migration of vascular smooth muscle cells via tyrosine phosphorylation and protein kinase C. Experimental and Molecular Medicine 2004b;36:103-9

Kim JH, Lee S, Kim JH, Lee TG, Hirata M, Suh PG, Ryu $\mathrm{SH}$. Phospholipase D2 directly interacts with aldolase via its $\mathrm{PH}$ domain. Biochemistry 2002;41:3414-21

Kim MS, Lee YT, Kim JM, Cha JY, Bae YS. Characterization of protein interaction among subunits of protein kinase CKII in vivo and in vitro. Molecules and Cells 1998;8:43-8

Kim Y, Han JM, Han BR, Lee KA, Kim JH, Lee BD, Jang $\mathrm{IH}$, Suh PG, Ryu SH. Phospholipase D1 is phosphorylated and activated by protein kinase $\mathrm{C}$ in caveolin-enriched microdomains within the plasma membrane. Journal of Biological Chemistry 2000;275:13621-7

Landesman-Bollag E, Channavajhala PL, Cardiff RD, Seldin DC. p53 deficiency and misexpression of protein kinase CK2alpha collaborate in the development of thymic lymphomas in mice. Oncogene 1998;16:2965-74

Landesman-Bollag E, Song DH, Romieu-Mourez R, Sussman DJ, Cardiff RD, Sonenshein GE, Seldin DC. Protein kinase CK2: signaling and tumorigenesis in the mammary gland. Molecular and Cellular Biochemistry 2001;227:153-65

Litchfield DW. Protein kinase CK2: structure, regulation and role in cellular decisions of life and death. Biochemical Journal 2002;369:1-15

Marin O, Meggio F, Draetta G, Pinna LA. The consensus sequences for cdc2 kinase and for casein kinase-2 are mutually incompatible. A study with peptides derived from the beta- subunit of casein kinase-2. FEBS Letter 1992; 301:111-4

Min DS, Ahn BH, Rhie DJ, Yoon SH, Hahn SJ, Kim MS, Jo $\mathrm{YH}$. Expression and regulation of phospholipase $\mathrm{D}$ during neuronal differentiation of PC12 cells. Neuropharmacology 2001;41:384-91

Min DS, Kim EG, Exton JH. Involvement of tyrosine phosphorylation and protein kinase $\mathrm{C}$ in the activation of phospholipase $\mathrm{D}$ by $\mathrm{H}_{2} \mathrm{O}_{2}$ in Swiss $3 \mathrm{~T} 3$ fibroblasts. Journal of Biological Chemistry 1998;273:29986-94

Min DS, Park SK, Exton JH. Characterization of a rat brain phospholipase $D$ isozyme. Journal of Biological Chemistry 1998;273:7044-51 
Pinna LA. Casein kinase 2: an 'eminence gris' in cellular regulation? Biochimica et Biophysica Acta 1990;1054:267-84

Pinna LA, Meggio F. Protein kinase CK2 (casein kinase-2) and its implication in cell division and proliferation. Progress in Cell Cycle Research 1997;3:77-97

Sanghera JS, Charlto LA, Paddon HB, Pelech SL. Purification and characterization of echinoderm casein kinase II. Regulation of protein kinase C. Biochemical Journal 1992;283: 829-37

Seldin DC, Leder P. Casein kinase II alpha transgene- induced murine lymphoma: relation to theileriosis in cattle. Science 1995;267:894-7
Silva-Neto MA, Carneiro AB, Vieira DP, Mesquita RD, Lopes $\mathrm{AH}$. Platelet-activating factor (PAF) activates casein kinase 2 in the protozoan parasite Herpetomonas muscarum muscarum. Biochemical and Biophysical Research Communications 2002;293:1358-63

Xu X, Toselli PA, Russell LD, Seldin DC. Globozoospermia in mice lacking the casein kinase II alpha' catalytic subunit. Nature Genetics 1999;23:118-21 